\title{
医療機関を対象にした新規水処理技術の開発
}

\author{
東 剛 志
}

\section{Newly Designed Water Treatment Systems for Hospital Effluent}

\author{
Takashi Azuma \\ Graduate School of Pharmaceutical Sciences, Osaka University of Pharmaceutical \\ Sciences; 4-20-1 Nasahara, Takatsuki, Osaka 569-1094, Japan.
}

(Received July 21, 2017)

\begin{abstract}
Pharmaceuticals are indispensable to contemporary life. Recently, the emerging problem of pharmaceutical-based pollution of river environments, including drinking water sources and lakes, has begun to receive significant attention worldwide. Because pharmaceuticals are designed to perform specific physiological functions in targeted regions of the human body, there is increasing concern regarding their toxic effects, even at low concentrations, on aquatic ecosystems and human health, via residues in drinking water. Pharmaceuticals are consistently employed in hospitals to treat disease; and Japan, one of the most advanced countries in medical treatment, ranks second worldwide in the quantity of pharmaceuticals employed. Therefore, the development of technologies that minimize or lessen the related environmental risks for clinical effluent is an important task as well as that for sewage treatment plants (STPs). However, there has been limited research on clinical effluent, and much remains to be elucidated. In light of this, we are investigating the occurrence of pharmaceuticals, and the development of water treatment systems for clinical effluent. This review discusses the current research on clinical effluent and the development of advanced water treatment systems targeted at hospital effluent, and explores strategies for future environmental risk assessment and risk management.
\end{abstract}

Key words_- hospital effluent; pharmaceutical; water environment; sewage treatment plant; water treatment system

\section{1. はじめに}

現在，われわれの身の回りには化学物質が溢れて いる。米国化学会の Chemical Abstracts Service (CAS) に登録されている化学物質数は，2011 年に 6000 万種であったものが，2017 年には 13000 万成 分1) とここ数年で急激な増加傾向にある。これらの 化学物質の中には, 疾病の治療や診断, さらには現 代における豊かな生活をおくる上で必要不可欠と なっている医薬品及びその関連製品成分についても 含まれている.

化学物質による環境污染問題は, 1962 年にレイ チェル・カーソンが「沈黙の春」2)においてその危 険性について警鐘を鳴らしているように，近代化が 進むにつれて農薬, ${ }^{3)}$ ダイオキシン4)等の問題が顕 在化する事例が発生するようになってきた。特に，

大阪薬科大学大学院薬学研究科（T569-1094 大阪府高 槻市奈佐原 4 丁目 20 番 1 号)

e-mail: t.azuma@gly.oups.ac.jp

本総説は, 日本薬学会第 137 年会シンポジウム S46 で 発表した内容を中心に記述したものである.
1990 年代には環境ホルモン問題が社会問題化し, 法規制の整備を含め国を挙げての対策が行われ, 5) 評価と対策に関する研究が継続して進められてい る.このような状況のなか， 2000 年代には医薬品 を始め化粧品・日焼け止めといった日用品（以下医 薬品類）が，飲料水源を含めて河川や湖沼中に流出 して残留する新たな環境污染問題が世界的な規模で 進行していることが明らかになり, ${ }^{6,7)}$ 污染実態や環 境中での挙動に関する研究や，生態系への毒性影響 評価，除去手法の開発等，多岐に渡る研究が行われ つつある. ${ }^{8-11)}$

エルゼビアが提供している，世界最大級の抄録・

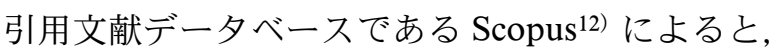
医薬品類よる環境污染問題で用いられる代表的な キーワードとなっている pharmaceuticals and personal care products (PPCPs) ${ }^{13)}$ に関して, Analysis, Water Environment, Removal, Toxicity といつた様 々な領域から検討を試みる研究事例が年々増加傾向 にあることがうかがえる（Fig. 1)。また， Resistance といつた薬剤耐性菌や薬剤耐性ウイルス 


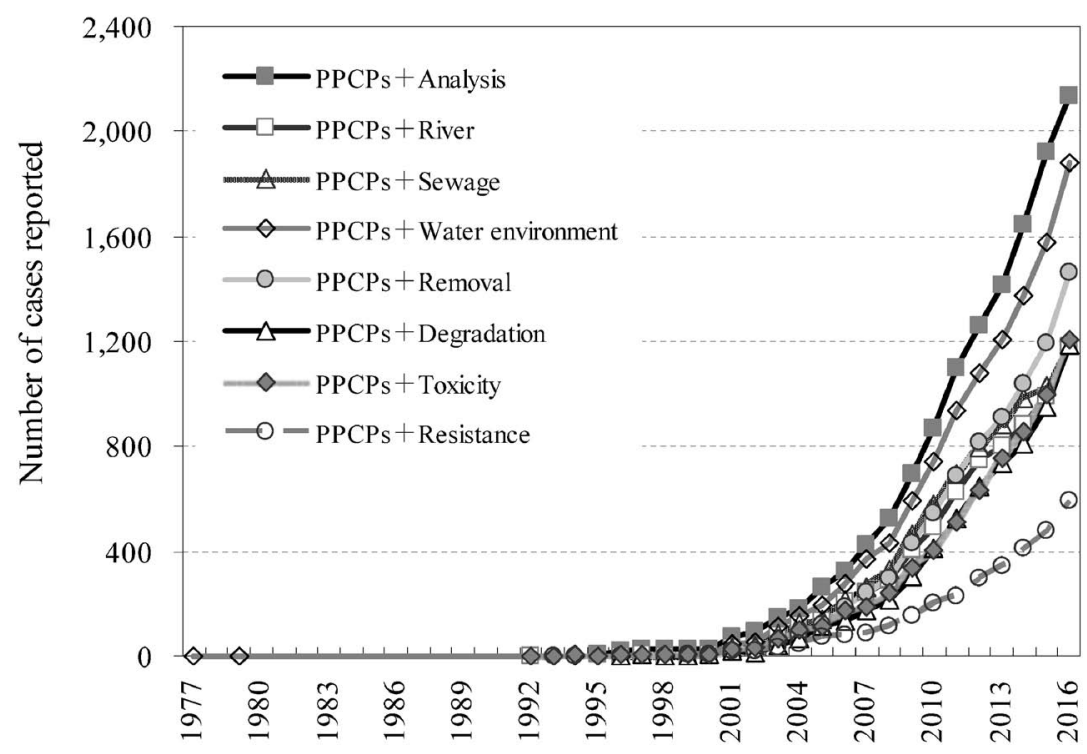

Fig. 1. Patterns in Reported Cases regarding PPCPs

発生との関連性に関する検討事例も近年増加傾向に あることも，特筆すべき点であると考えられる.こ れらのことは，医薬品が低濃度で体内の特定の部位 で特異的な薬理効果を発揮するようにデザインされ ているため, 医薬品が環境中に流出する際の影響が 懸念され, ${ }^{14,15)}$ この問題に対して詳細な評価と対策 を行うことが重要な課題となっていることを示唆し ていると考えられる.

ところで，医薬品類は病院等の医療機関で恒常的 に用いられている。 さらに，わが国は世界の中でも 医療技術が高度に発達した医療先進国であると同時 に，医薬品の消費大国でもあることが知られてい る. ${ }^{16)}$ そのため，医療機関に由来する排水中に存在 する医薬品類の実態を把握し，環境に対する影響に ついてのリスク評価を行うとともに，そのリスクを 削減，又は低減可能な技術開発についての研究を行 うことは，有効な解決方法の 1 つとなる可能性が考 えられる。しかしながら，医療排水を対象にした研 究事例は世界的にみても非常に限られており，不明 なことがいまだ多い状態にある。そこで，近年私た ちは医療機関と協力体制の下，医療排水を対象とし た調査を行い，医療排水中に存在する医薬品類の実 態を把握するとともに，除去に有効な新規処理技術 の開発研究を試みている.

本総説では，医療機関に由来する排水として病院 から公共下水道に放流される排水を対象に，医療排 水の現状，医薬品の存在実態と環境への負荷影響，
除去技術について近年明らかになりつつある最新の 知見を踏まえながら概説し，今後の環境リスク評 価・リスク管理の展望について報告する。

\section{2. 病院に関連する排水}

病院排水に関する研究事例は世界的に限られてお り，国内での状況もほとんど知られていないのが実 情である。ここでは，日本における病院排水の構成 と処理状況をまとめた数少ない報告である，日本医 師会総合政策研究機構のワーキングペーパー17)を基 に，病院に由来する排水についてまとめる.

病院排水は, 様々な種類の排水により構成されて いる. Figure 2 に病院排水の種類を分類したまとめ を示す，病院排水は，厨房からの排水やし尿，雑排 水といった一般的な雑排水のほかに, 実験系排水, 放射性排水，薬品系排水，感染系排水といった排水 が含まれている。

これらの排水を下水道に放流する際には，下水道 法18)に基づいて事業所等に適応される水温や $\mathrm{pH}$ 等 の基本的な水質のほか，重金属やダイオキシン等の 排水基準が適応されている。 また，放射性物質を取 り扱う施設においては，放射性排水の減衰処理は医 療法施行規則 ${ }^{19)}$ による法令により定められており， 減衰処理をした後に放流する，なお，公共下水道が 整備されていない区域では，浄化槽の設置義務が義 務付けられており, 20) 浄化槽内での生物処理と塩素 消毒を経た後，公共用水域等（300 床以上の病院に ついては水質污濁防止法 ${ }^{21)}$ による規制が適応され 


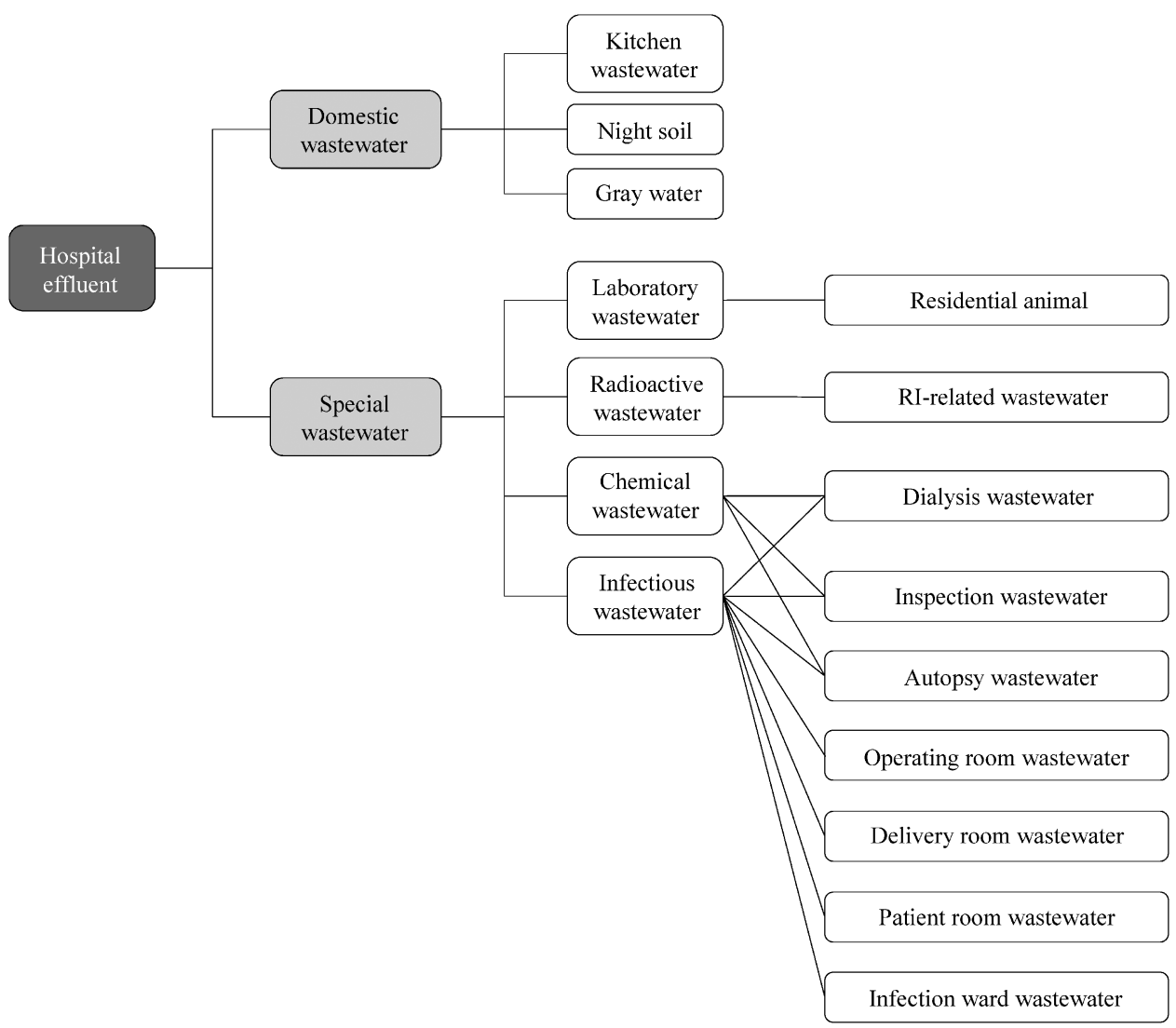

Fig. 2. Classification and Constitution of Hospital Wastewater

る）に放流される.

近年環境への影響が懸念されつつある医薬品類を 始めとした化学物質については，行政を始め製薬企 業においてもその評価と対策に関するガイドライン の作成等の検討が行われはじめている. ${ }^{22,23)}$ 一方 で，医療排水を対象にした取り組みについては途上 の状態にある．しかしながら，国内に存在する約 9000 施設の病院のうち, 無作為に抽出された約

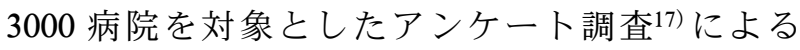
と, その数は約 $1 \%$ と限られているものの, 病院排 水に対して高度処理の導入を図っている病院が存在 することが報告されている。これらのことを踏まえ ると, 病院排水が有する影響について把握するとと もに，環境面に配慮した除去技術の開発を試みるこ とは，急速に発展を続ける現在社会において重要な 課題となる可能性が考えられる。

\section{3. 病院排水中に存在する医薬品成分}

病院から公共下水道に放流される排水について, 下水処理場や河川水中から検出されることが国内外 で報告されている医薬品成分のほか, ${ }^{24-26)}$ 国内での 生産量や販売高 ${ }^{27)}$ 及び未変化体での体外排泄割合 ${ }^{28)}$
を基に，医療現場で使用されている主要な医薬品成 分やその代謝物を合わせた 41 成分を対象として通 年での調査を行った，さらに，病院排水が有する環 境に対する影響について評価を試みるため, 病院排 水を処理区内に有する下水処理場の流入水と, 河川 へと放流される水処理後の放流水，そして河川にお

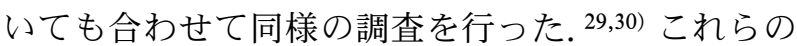
研究により得られた結果を, Fig. 3 にまとめている.

調査を行った病院排水中から, 対象とした医薬品 類 41 成分のうち 38 成分が数 $\mathrm{ng} / \mathrm{L}$-最大值で $92 \mu \mathrm{g}$ /L と, 非常に幅広い濃度で検出された。病院排水 中から検出された医薬品類は, 下水処理場の流入水 中からも同程度から 10 倍程度低濃度で検出される 傾向がみられた。一方で, ciprofloxacin, clarithomycin, levofloxacin といつた抗菌剂や, capecitabine, cyclophsophamide, tamoxifen といった抗がん剂, acetaminophen sulfate, loxoprofen, loxoprofen alcohol といつた解熱鎮痛剤については, 病院排水の方 が高濃度で検出される傾向がみられた。 また，抗ウ イルス剤の famciclovir, valaciclovir や抗がん剤の doxifluridine については病院排水中からのみ検出さ 


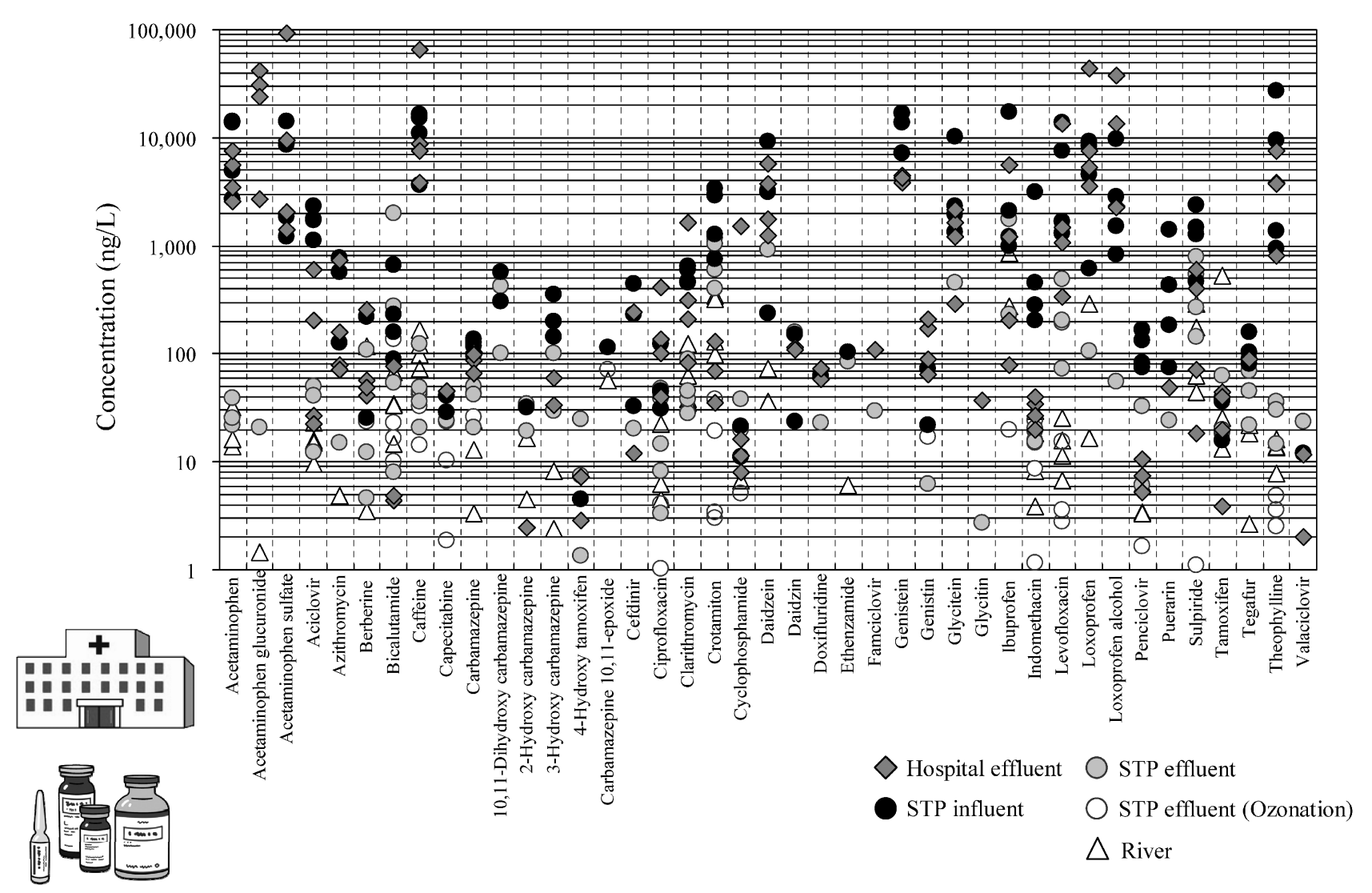

Fig. 3. Distribution of PPCPs in Hospital Effluent, STP Influent, STP Effluent, and River Water

れ，これらについては病院で用いられる機会が多い 成分であると考えられた。

下水処理場から検出される医薬品類は，下水処理 場の水処理工程で一部は除去されるが，多くの成分 については十分に除去されず，放流先の河川におい ても概ね類似した濃度で検出される傾向がみられ た。このことは，これまで報告されているように， 医薬品類が生物処理を中心とした従来型の下水処理 工程では除去され難い傾向にある31) ことが関係して いると考えられた。一方で，高度処理としてオゾン による水処理を行っている下水処理場の放流水中か らは, 医薬品類は検出されないか数 $\mathrm{ng} / \mathrm{L}-$ 数十 $\mathrm{ng}$ / $\mathrm{L}$ と, 下水処理場の放流水濃度の約 10 分の 1 から 100 分の 1 程度の濃度で検出される傾向がみられ た。これらの結果は，高度処理を導入することで, 従来型の水処理工程では除去が難しい医薬品類等を 除去可能であるとする報告 ${ }^{32,33)}$ の有用性を高めるも のであると考えられる.

\section{4. 水環境への負荷影響の推定}

各試料中に存在する医薬品類について, 検出濃度 に各地点の流量を考慮することで得られる負荷量を
基にして，各試料毎における医薬品の存在割合を薬 効分類毎にまとめたものを Fig. 4 に示す. ${ }^{29,30)}$

病院排水中に存在する医薬品類について, 本研究 で対象とした医薬品類の中で最も構成割合が高かっ た薬効成分は解熱鎮痛剤で $73.0 \%$ ，ついで theophylline や嗜好品にも含まれる caffeine といった 気管支拡張剂が $21.6 \%$ を占めていた。一方で，抗 ウイルス剂，抗菌剤，抗がん剂，向精神剂について は各々 $0.2 \%, 4.3 \%, 0.4 \%, 0.3 \%$ であた。これら の結果については，海外の報告（解熱鎮痛剤 26-56 \%, 気管支拡張剂 12-57\%，抗ウイルス剂十抗菌剂 2-8\%，向精神剂 6-20\%) 25,34,35) と比較した際には, 解熱鎮痛剂や気管支拡張剂については 0.4 倍一最大 1.8 倍，抗菌剂や抗がん剤の使用傾向は海外と概ね 類似した值になっており，その他の成分については 1 オーダー程度低い值になっていた。このことは, 各国間で病院における医薬品の使用傾向が若干異な る傾向にあることを反映していると考えられる.

一方で，下水処理場流入水中に存在する医薬品類 の構成割合については, 抗ウイルス剤, 抗菌剤, 抗が ん剂, 向精神剂の構成割合は各々 $2.8 \%, 10.8 \%, 0.7 \%$, 
(a) Hospital effluent

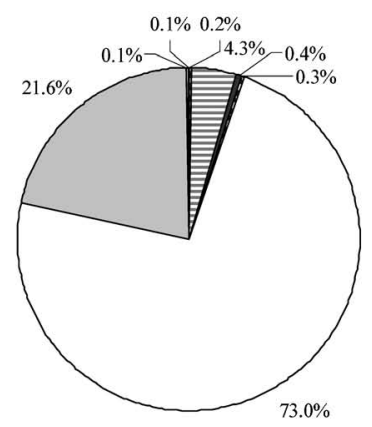

(c) STP effluent



(b) STP influent

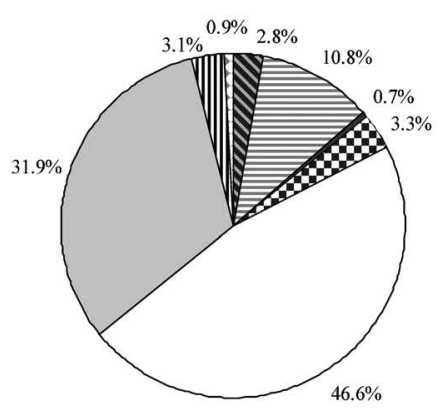

(d) River water

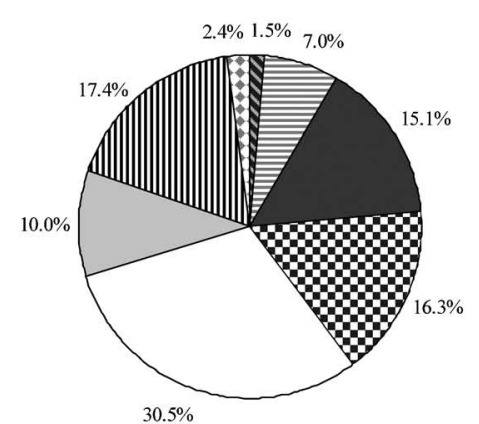

Anti-viral

目 Anti-bacterial

Anti-cancer

Psychotropic

$\square$ Analgesic-antipyretic

$\square$ Bronchodilator

س Anti-pruritic

$\checkmark$ Herbal medicine

Fig. 4. Contribution of Pharmaceuticals in Water Samples from (a) Hospital Effluent, (b) STP Influent, (c) STP Effluent, and (d) River Water

The limit of quantification values for the water samples were $\leq 1 \mathrm{ng} / \mathrm{L}$.

$3.3 \%$ と病院排水の構成割合よりも約 2-15 倍高い傾 向がみられ，一般家庭における医薬品類の使用によ る影響を受けていることが原因と考えられた. なお, 下水処理場放流水と河川水の医薬品類の構成割合は 概ね類似した傾向がみられ，調査を行った流域では 下水処理場放流水由来の污濁負荷割合が大きいと考 えられた.このことは, 河川環境に流入する医薬品 類の污濁負荷を削減するために，水処理技術の高度 化を図ることの重要性を示唆していると考えられた。

下水処理場の流入水中に占める病院排水由来の医 薬品類の寄与割合については, 医薬品の種類毎に寄 与割合が異なり， $0.1 \%$-最大 $15 \%$ と幅広い範囲に 分布していること，抗菌剤や抗がん剂といった成分 については病院排水に由来する負荷割合が高くなる 傾向がみられた。このことは, 臨床現場での薬剤の 使われ方が関係していると考えられた。ささらに，本 研究で対象とした病院の排水を処理している下水処 理場の処理区域内に位置する医療機関を考慮し, 病 床数を考慮してある地域に位置する病院全体が占め る寄与割合の推計を行ったところ, 寄与割合は 数\%一最大 $40 \%$ で分布すると推定され, 病院に由来 する医薬品の環境への負荷影響は少なくないことが
考えられた。一方で, 河川水への下水処理場放流水 由来の寄与率は数\% $-177 \%$ となっており, 既報研 究36,37)でも報告されているように, 河川への污濁負 荷影響として下水処理場が占める寄与割合が大きく なる傾向がみられた。

これまでの研究により, 欧米における研究事例で は, 病院排水に由来する医薬品類の負荷量の割合が 60\%近くにまで及ぶ事例もあることが報告されてい るが, ${ }^{25,38)}$ 医療先進国で知られる日本において, 病 院排水に存在する医薬品成分の存在実態と污濁負荷 影響を詳細に評価したのは, 本研究が初めての報告 となった.これらの結果は, 河川環境中に放流され る医薬品成分の污濁負荷を削減又は軽減するために 有効な対策として，下水処理場における処理技術の 高度化を進めていくことに加えて, 医療機関におい ても公共下水道に放流する前に水処理を行うことが 有効な対策となる可能性を示唆していると考えられ た. 今後, 対象とする成分を始め, 医療機関や地域 についても拡張して詳細な検討を行い，更なる知見 の収集に努めることが重要であると考えられた。

\section{5. 病院排水に適応可能な水処理技術の開発}

病院排水に適応可能な水処理技術の開発を行う目 
Table 1. Removal Efficiency of PPCPs in Various Forms of Water Treatment Systems

\begin{tabular}{|c|c|c|c|c|c|c|c|c|}
\hline \multirow{2}{*}{ Therapeutic class } & \multicolumn{8}{|c|}{ Treatment system } \\
\hline & $\begin{array}{l}\text { Biological } \\
\text { treatment }\end{array}$ & UV & $\mathrm{H}_{2} \mathrm{O}_{2}$ & $\mathrm{UV} / \mathrm{H}_{2} \mathrm{O}_{2}$ & $\mathrm{O}_{3}$ & $\mathrm{O}_{3} / \mathrm{UV}$ & $\mathrm{O}_{3} / \mathrm{H}_{2} \mathrm{O}_{2}$ & $\mathrm{O}_{3} / \mathrm{UV} / \mathrm{H}_{2} \mathrm{O}_{2}$ \\
\hline Anti-viral & $\Delta \sim 0$ & $x \sim \triangle$ & $x$ & $\Delta \sim 0$ & O 0 & O ( & $O \sim 0$ & O ( ) \\
\hline Anti-bacterial & $x \sim \triangle$ & $\Delta \sim 0$ & $x \sim \triangle$ & O ( ) & $O \sim 0$ & (2) & (2) & (2) \\
\hline Anti-cancer & $\Delta \sim 0$ & O O & $\times$ & $\Delta \sim 0$ & O O & () & () & $O \sim 0$ \\
\hline Psychotropic & $x \sim \triangle$ & $x \sim \triangle$ & $\times$ & $\Delta \sim 0$ & $\Delta \sim 0$ & $0 \sim 0$ & $\Delta \sim 0$ & $O \sim 0$ \\
\hline Analgesic-antipyretic & $O \sim 0$ & $\Delta \sim 0$ & $\times$ & O & O O & $O \sim 0$ & $O \sim 0$ & O O \\
\hline Bronchodilator & $x \sim \triangle$ & $x \sim \triangle$ & $\times$ & O & ( ) & (2) & (2) & (2) \\
\hline Anti-pruritic & $x \sim \triangle$ & $\bigcirc$ & $x$ & O & (0) & (2) & (2) & (0) \\
\hline Herbal medicine & (2) & $\triangle$ & $x \sim \triangle$ & O & ( ) & ( ) & (2) & ( ) \\
\hline Phytoestrogen & (2) & $\triangle$ & $x$ & O ( ) & (0) & (0) & (0) & (0) \\
\hline
\end{tabular}

$\times$ : Persistent; $\triangle$ : Gradually degradable; $\bigcirc$ : Degradable; $\bigcirc: \leq$ Readily degradable.

的で，医薬品類を対象にしてラボスケールにおける 各種水処理技術の有効性の評価を行った. ${ }^{30,39)}$ 水処 理技術の検討では，下水処理場の水処理工程で主た る処理工程となっている生物処理に加えて, 項目 3 及び項目 4 で述べた高度処理の有効性についても評 価を行う目的で，過酸化水素やUVに加え，オゾン を用いた処理技術についてもあわせて検討を行つ た. 各水処理工程での医薬品類の除去の有効性につ いてまとめたものを Table 1 に示す.

生物処理による処理工程では，対象とした成分の うち概ね 3-4 割の成分については 90\%以上の除去 率が得られていた。一方で，生物処理で十分な除去 が見込めない成分も多く存在しており, carbamazepine, cyclophosphamide, ethenzamide, iomeprol, iopamidol, indomethacin, olmesartan, tegafur につ いては，生物処理による除去率は 0-22\% と低く, 難分解性を示す成分であると考えられた。 これらの 結果については, これまでの研究により, 生物処理 を中心とする下水処理場の水処理工程では医薬品成 分が十分に除去され難い傾向にあることが報告され ている40)ことを踏まえると，概ね妥当な結果である と考えられた。しかしながら，医療排水を対象にし た生物処理工程で下水処理場の生物処理工程と同程 度の除去率が得られたことは，医療機関に由来する 排水についても一部の医薬品成分については生物処 理による水処理技術で除去可能であることを示唆し ていると考えられた。

UV 単独による処理では，顕著な除去がみられる
成分も存在していたが，効率よく除去可能な成分に ついては生物処理の場合と同様に，対象とした成分 のうち概ね 3-4 割に限られていた。過酸化水素単独 による処理では，ほとんどの成分に対して難分解性 を示す傾向がみられた。一方で，UV と過酸化水素 を組み合わせた系では，除去可能な成分が顕著に増 加する傾向がみられた。これは，UV を照射するこ とで過酸化水素から $\mathrm{OH}$ ラジカルを始めとする酸 化力の強い活性酸素類が発生する41,42) ことに起因し ていると考えられた.

オゾンをべースとした処理では，対象とした医薬 品類の大部分の医薬品成分が速やかに除去されてお り, 反応開始後数分 -10 分以内でほぼ全量が除去さ れた。このことは, 下水処理場における調査で得ら れた結果を考慮しても妥当な結果であり，オゾン処 理が医薬品類の処理に有効であることが示唆された. さらに，過酸化水素の場合と同様に，オゾンにUV や過酸化水素を併用することで，付加的な除去効率 への影響が期待されることを明らかにした。一方で, オゾンをべースにした除去法を用いた場合でも，効 果的な除去率を得るためには長時間を要する成分 (bicalutamide, cyclophosphamide, loxoprofen) もわ ずかではあるが存在していた.これらの成分について は, 処理条件について検討を行い更なる除去効率の向 上を図ることに加え，オゾン処理以外の処理方法に ついても検討を行うことが重要であると考えられた。

水処理技術の高度化を図ることで, 環境污染物質 としての医薬品成分の環境中への流入の削減を行う 
ことが可能であることは明らかであると考えられ る. 一方で，これらの高度処理については，処理技 術を高度化するに従い, 又は複数の方式を組み合わ せるに従いより処理に要するコストが増加する傾向 にあることが，実際面での課題として残っている. そのため，実際の導入を考えた実用面やコスト面に ついても考慮して, 今後更なる検討を行っていくこ とが重要であると考えられる。また，河川環境中に 流入する医薬品に対する環境リスク評価に関する研 究とあわせて, 求められる削減レベルの整備を推進 するとともに，環境面から新たな創薬戦略について も発展させていくことが重要であると考えられる.

\section{6. まとめ}

本総説では，近年世界的な規模で污染が進行して いることが明らかにされつつある医薬品類による環 境污染問題について，医療機関に由来する排水を対 象に，医療排水の現状，医薬品の存在実態と環境へ の負荷影響，そして処理技術の有効性評価について の研究例について紹介を行い, 今後の環境リスク評 価・リスク管理の展望について考察を行つた.

医薬品類による環境污染問題は，医薬品と環境と のつながりについて考えることの重要性を示唆して おり，近代的で豊かな生活と持続可能な発展・人類 の繁栄についての共存点とバランスというテーマに も関係するものである。本研究で得られた成果が, 医薬品の適正使用を推進するとともに，医療従事者 側で対応可能な環境面への配慮のあり方や，環境に 優しいこれからの医薬品のあり方を探る上でも，有 益な知見となり得ることが期待される.

\section{謝辞＼cjkstart本研究を行うにあたり，採水にご協力下} さいました病院，河川及び下水処理場の関係者の方 々，標準物質をご提供下さいました製薬会社の関係 者の方々に厚く御礼申し上げます。また，大阪薬科 大学学術交流推進委員会の皆様に「創薬と環境」プ ロジェクトに関してご支援を頂きました。本研究 は，科学研究費助成事業 (16K16218), 琵琶湖・淀 川水質保全機構，河川環境管理財団（25-1263-024, 26-1263-017, 27-1263-019)，住友財団（153018）, クリタ水・環境科学振興財団 (14E007), 前田記念 工学振興財団から一部助成を受けて実施しました.

利益相反＼cjkstart開示すべき利益相反はない，

\section{REFERENCES}

1) American Chemical Society, Chemical Abstracts Service (CAS): 〈https://www.cas. org/ $\rangle$, cited 24 June, 2017.

2) Carson R., "'Silent Spring," Houghton Mifflin Co., Boston, 1962.

3) Ritter W. F., J. Environ. Sci. Health B, 25, 129 (1990).

4) Fletcher C. L., McKay W. A., Chemosphere, 26, 1041-1069 (1993).

5) Ministry of the Environment, "Strategic programs on environmental endocrine disruptors '98 (SPEED '98).": 〈http://www.env.go. jp/>, cited 24 June, 2017.

6) Kolpin D. W., Furlong E. T., Meyer M. T., Thurman E. M., Zaugg S. D., Barber L. B., Buxton H. T., Environ. Sci. Technol., 36, 1202-1211 (2002).

7) Ternes T. A., Water Res., 32, 3245-3260 (1998).

8) Luo Y., Guo W., Ngo H. H., Nghiem L. D., Hai F. I., Zhang J., Liang S., Wang X. C., Sci. Total Environ., 473-474, 619-641 (2014) .

9) Arpin-Pont L., Bueno M. J. M., Gomez E., Fenet H., Environ. Sci. Pollut. Res., 23, 49784991 (2016).

10) Montes-Grajales D., Fennix-Agudelo M., Miranda-Castro W., Sci. Total Environ., 595, 601-614 (2017) .

11) Tiedeken E. J., Tahar A., McHugh B., Rowan N. J., Sci. Total Environ., 574, 1140-1163 (2017).

12) Elsevier, "Scopus": 〈https://www.scopus. com/home.uri $\rangle$, cited 24 June, 2017.

13) Daughton C. G., Ternes T. A., Environ. Health Perspect., 107, 907-938 (1999).

14) Vasquez M. I., Lambrianides A., Schneider M., Kümmerer K., Fatta-Kassinos D., J. Hazard. Mater., 279, 169-189 (2014) .

15) Kümmerer K., Chemosphere, 75, 417-434 (2009).

16) Ministry of Health, Labour and Welfare, "Pharmaceutical industry vision 2013.": 〈http://www.mhlw.go.jp/stf/seisakunitsuite/ bunya/kenkou_iryou/iryou/shinkou/index. html $\rangle$, cited 24 June, 2017.

17) Mori K., Japan Medical Association Research 
Institute, Working Paper, No. 158, pp. 1-117, 2008.

18) Ministry of Internal Affairs and Communications, "Japan Sewerage Law.": 〈http://law.egov.go.jp / htmldata / S33 / S33HO079.html >, cited 24 June, 2017.

19) Ministry of Health, Labour and Welfare, "Medical Care Act enforcement regulations.": 〈http://law.e-gov.go.jp/htmldata/ S23 / S23F03601000050.html \# 10000000000040 0000000500000000000000000000000000000000 $000000000000000000000000\rangle$, cited 24 June, 2017.

20) Ministry of Internal Affairs and Communications, "Private Sewerage System Act.": 〈http: //law.e-gov.go.jp/htmldata/S58/S58HO043. html $\rangle$, cited 24 June, 2017.

21) Ministry of Internal Affairs and Communications, "Japan Water Pollution Prevention Law.": 〈http://law.e-gov.go.jp/htmldata/ S45/S45HO138.html , cited 24 June, 2017.

22) Caldwell D. J., Mertens B., Kappler K., Senac T., Journel R., Wilson P., Meyerhoff R. D., Parke N. J., Mastrocco F., Mattson B., Murray-Smith R., Dolan D. G., Straub J. O., Wiedemann M., Hartmann A., Finan D. S., Environ. Toxicol. Chem., 35, 813-822 (2016) .

23) Ministry of Health, Labour and Welfare, "Guidance for environmental risk assessment in new drug development.”: 〈http://www. japal.org/wp-content/uploads/mt/pdf/notice /20160330_sk0330-1.pdf $\rangle$, cited 24 June, 2017.

24) Azuma T., Ishiuchi H., Inoyama T., Teranishi Y., Yamaoka M., Sato T., Mino Y., Environ. Sci. Pollut. Res., 22, 18676-18686 (2015) .

25) Oliveira T. S., Murphy M., Mendola N., Wong V., Carlson D., Waring L., Sci. Total Environ., 518-519, 459-478 (2015).

26) López-Serna R., Jurado A., Vazquez-Suñé E., Carrera J., Petrović M., Barceló D., Environ. Pollut., 174, 305-315 (2013).

27) Ministry of Health, Labour and Welfare, "Annual report on statistics of production by pharmaceutical industry in 2014.": 〈http:// www.mhlw.go.jp/topics/yakuji/2014/nenpo/ index.html $\rangle$, cited 24 June, 2017.

28) Lienert J., Güdel K., Escher B. I., Environ. Sci. Technol., 41, 4471-4478 (2007).
29) Azuma T., Arima N., Tsukada A., Hirami S., Matsuoka R., Moriwake R., Ishiuchi H., Inoyama T., Teranishi Y., Yamaoka M., Mino Y., Hayashi T., Fujita Y., Masada M., Sci. Total Environ., 548-549, 189-197 (2016) .

30) Azuma T., Arima N., Tsukada A., Hirami S., Matsuoka R., Moriwake R., Ishiuchi H., Inoyama T., Teranishi Y., Yamaoka M., Mino Y., Hayashi T., Fujita Y., Masada M., Abstracts of papers, IWA World Water Congress \& Exhibition, Brisbane, October 2016.

31) Michael I., Rizzo L., McArdell C. S., Manaia C. M., Merlin C., Schwartz T., Dagot C., Fatta-Kassinos D., Water Res., 47, 957-995 (2013).

32) Kim I. H., Yamashita N., Kato Y., Tanaka H., Water Sci. Technol., 59, 945-955 (2009) .

33) Antoniou M. G., Hey G., Rodríguez Vega S., Spiliotopoulou A., Fick J., Tysklind M., la Cour Jansen J., Andersen H. R., Sci. Total Environ., 456-457, 42-49 (2013).

34) Ferrando-Climent L., Rodriguez-Mozaz S., Barceló D., Environ. Pollut., 193, 216-223 (2014).

35) Al Aukidy M., Verlicchi P., Voulvoulis N., Sci. Total Environ., 493, 54-64 (2014) .

36) Azuma T., Nakada N., Yamashita N., Tanaka H., Chemosphere, 93, 1672-1677 (2013).

37) Kumar V., Hanamoto S., Johnson A. C., Yamashita N., Nakada N., Tanaka H., Environ. Sci. Proc. Imp., 16, 232-238 (2014) .

38) Santos L. H. M. L. M., Gros M., RodriguezMozaz S., Delerue-Matos C., Pena A., Barceló D., Montenegro M. C. B. S. M., Sci. Total Environ., 461-462, 302-316 (2013).

39) Azuma T., Abstracts of papaers, the 137th Annual Meeting of the Pharmaceutical Society of Japan, Sendai, March 2017, p. 235.

40) Prasse C., Stalter D., Schulte-Oehlmann U., Oehlmann J., Ternes T. A., Water Res., 87, 237-270 (2015).

41) Keen O. S., Baik S., Linden K. G., Aga D. S., Love N. G., Environ. Sci. Technol., 46, 62226227 (2012).

42) Lee Y., Gerrity D., Lee M., Gamage S., Pisarenko A., Trenholm R. A., Canonica S., Snyder S. A., von Gunten U., Environ. Sci. Technol., 50, 3809-3819 (2016). 